\title{
Effect of Weeding Frequency on Yield an Yield Components of Food Barley (Horduem vulgare L.) Varieties at Amuru District, Horo Guduru Wollega Zone of Oromia, Ethiopia
}

\author{
Dessalegn Ayana ${ }^{1}$, Habtamu Ashagre ${ }^{2}$, Ibrahim Hamza ${ }^{3}$ \\ ${ }^{1}$ Department of Plant Science, College of Agriculture and Natural Sciences, Assosa University, Assoas, Ethiopia \\ ${ }^{2}$ Department of Plant Sciences, College of Agriculture and Veterinary Sciences, Ambo University, Ambo, Ethiopa \\ ${ }^{3}$ School of Agriculture and Agricultural Technology, Federal University of Technology, Minna, Nigeria
}

\section{Email address:}

ayanadessalegn074@gmail.com (D. Ayana)

\section{To cite this article:}

Dessalegn Ayana, Habtamu Ashagre, Ibrahim Hamza. Effect of Weeding Frequency on Yield an Yield Components of Food Barley (Horduem vulgare L.) Varieties at Amuru District, Horo Guduru Wollega Zone of Oromia, Ethiopia. Journal of Plant Sciences.

Vol. 9, No. 2, 2021, pp. 32-37. doi: 10.11648/j.jps.20210902.11

Received: November 30, 2020; Accepted: January 12, 2021; Published: April 16, 2021

\begin{abstract}
An experiment was conducted to identify better performing food barley cultivar at Amuru District of Horo Guduru Wollega Zone of Oromia National Regional State of Ethiopia in 2016 main cropping season. The experiment was laid down in a Randomized Complete Block Design (RCBD) with three replications. The treatments were factorial combination of four weeding frequencies (weedy check, one time weeding, two times weeding and three times weeding) and five food barley cultivars (HB-1307, CROSS 41/98, GOBE, EH1493 and Local). Yield and yield components of barley including spike length, thousand kernel weight, grain yield and biological yield were significantly influenced by main effect of variety and weeding frequency. However, number of productive tillers, kernels per spike, and harvest index were significantly influenced by interaction effect of variety and weeding frequency. HB-1307 variety gave significantly higher grain yield (1292 kgha $\left.{ }^{-1}\right)$ than the other four barley cultivars. Three times weeded treatment gave significantly higher grain yield $\left(1422 \mathrm{kgha}^{-1}\right)$ followed by two times weeded $\left(1000 \mathrm{kgha}^{-1}\right)$, one times weeded $\left(644 \mathrm{kgha}^{-1}\right)$ and weedy check $\left(511 \mathrm{kgha}^{-1}\right)$. Three times weeding of barley is the optimal weeding frequency and use of HB-1307 variety is better to increases grain yield in the area. However, need to be developing site specific varieties to the study area as the yield of improved varieties less performed.
\end{abstract}

Keywords: Food Barley, Weed, Weeding Frequency, Yield, Yield Components

\section{Introduction}

Barley (Hordeum vulgare L.) is one of the most important cereal crop in Etioppia. The crop has importance in the national diets of Ethiopia. In spite of the importance of barley as a food and malting crop, and the efforts made so far to generate improved production technologies, its productivity in production field has remained very low $\left(1.3\right.$ tha $^{-1}$ compared with the world average of 2.4 tha $^{-1)}$ [1]. Research in different part of the world has shown that yields of 10 tha $^{-1}$ can be obtained under intensive management [2]. However, the cause for low productivity in Ethiopia is attributed to abiotic stress include low soil fertility, low soil $\mathrm{pH}$ poor soil drainage, frost, and drought. As well as important biotic stresses are includes weed, diseases such as scald, net blotch, spot blotch, and rusts and insect pests such as aphids, and barley shoot fly [3]. Moreover, the level of adoption of improved barley production technologies by farmers is low, which is associated mainly with their minimal participation during the research process.

Barley is one of the commonly grown food security crops in higher altitude areas of Ethiopia. It is also the most important crop in Horo Guduru Wollega Zone, Oromia National Regional State. The total number of households cultivating barley in Horo Guduru Wollega Zone is estimated to be 32,305 , while, the number of households cultivating barley in Amuru district is estimated to be 6852. The total barley coverage in the district is estimated to be 4234 ha, and its productivity is half of the national average yield.

Barley is a crop plant which is very sensitive to weed 
competition and suffers the greatest yield reduction through competition, with significant yield loss when the crop received no weed control. Grass and sedge are more problematic weeds in barley production than broad leaf species because of selective nature of herbicides. Under such partial weed management, it is common to observe barley field infested with grass weed causing yield loss of up to $60 \%$ in many barley growing areas [4]. Weeds also can play a significant role in harboring insects, serving as alternative hosts for some diseases, and adding cost of production. Nevertheless barley genotypes vary in responses to the adverse effects of weeds. Therefore, farmers in the study area used local cultivar and the effect of weeding frequency on yield and yield component different varieties were not studied. Moreover, weed competition effect on barley yield was unknown and needs to be investigated. Hence, the objective of the study was to determine the optimal weeding frequency for food barley and to identify the best performing variety to the study area.

\section{Materials and Methods}

\subsection{Description of the Study Area}

The experiment was conducted at Amuru District which is found in the Eastern part of Horo Guduru Wollega Zone of Oromia National Regional state, which is far $387 \mathrm{~km}$ from Addis Ababa, during main rainy season of 2016. According to Oromia Sustainable Land Management Program [5] the study area extended from $36^{\circ}$ to $37^{\circ}$ East longitude to $9^{\circ}$ to $10^{\circ}$ North latitude. More than $75 \%$ of the area falls within altitude range of greater than $2300 \mathrm{~m}$ a. s. 1. The mean annual temperature varies between $15^{\circ} \mathrm{C}$ and $27^{\circ} \mathrm{C}$. The soil of the experimental site was deep alluvial with a sub soil stratified with loam, and clay loam dominated by loam with high amount of Aluminum and Iron oxides on the bases of color.

\subsection{Experimental Design and Treatments}

A four improved cultivars and one local variety were used for the study as experimental material. Five barley cultivars (HB-1407, CROSS41/98, EH1493, GOBE, and LOCAL) and four weeding frequencies (weedy check, one time weeding (20 DAS), two times weeding (20 and 40 DAS) and three time weeded (20, 40 and 60 DAS) were factorial combined to make a total of 20 treatments. Randomize Complete Block Design (RCBD) in factorial arrangement was adopted in three replications. The plot size used was 2 x $3 \mathrm{~m}$ with spacing between plots of $0.5 \mathrm{~m}$ and $0.75 \mathrm{~m}$ between blocks. Thus, spacing between rows were $20 \mathrm{~cm}$ using $85 \mathrm{~kg} \mathrm{ha}^{-1}$ seed rate for each treatment and seven inner rows were considered as a net plot. The outer most rows on both side of each plot were considered as a border. Treatments were randomly assigned.

\subsection{Experimental Field Management Practices}

Land preparation was done with three times ploughing from May up to mid-June 2016 by using Oxen plough. Planting was done on 29 June 2016 by placing the seeds in hand made furrows. Fertilizer levels for different treatments were calculated depending on recommended rates. Full dose of phosphate fertilizer in the form of Di-Ammonium Phosphate at the rate of $26 \mathrm{~kg} \mathrm{ha}^{-1}$ was applied equally to all plots at the depth of $2 \mathrm{~cm}$ below seeds at time of sowing. While the recommended rate of Nitrogen (40 kg ha-1) fertilizer in the form of Urea was applied in split form. Two third of Nitrogen fertilizer was applied at time of sowing and one third of the remaining fertilizer was applied at four leaf stage of barley to all treatment uniformly.

Weeds were managed by hand as per treatment and other agronomic practices were applied uniformly to all plots following the recommended practices for the crop. Harvesting was done when the spikes and leaves turned yellow. The harvested produce was sun dried for 14 days. Threshing and winnowing was done simultaneously and manually.

\subsection{Data Collection and Measurements}

Plant height was measured from the ground level to the top of spike excluding of the awn on ten randomly taken plants from the middle rows during maturity stage. The spike length from ten sampled plants were also measured and recorded at physiological maturity stage. Number of kernels per spike was counted on the spike of the main tillers of ten randomly sampled plants. Biological yield was measured by weighing the total sundried aboveground plants parts in kilogram from each plot. Grain yield was measured as a total grain yield from the net plot and converted to hectare base. The weight of 1000 seeds of randomly sampled grain weight was measured and recorded for yield data parameter for each treatment. Harvest index was calculated using the ratio of economic yield to biological yield expressed in percent as described by Fageria [6].

\subsection{Data Analysis}

The collected data was subjected to analysis of variance (ANOVA) according to the Generalized Linear Model (GLM) procedure of SAS Version 9.3 Software [7] and interpretations was made following the procedure of Gomez and Gomez [8]. Mean separations were done using Least Significance Difference (LSD) test at $5 \%$ or $1 \%$ level of significance.

\section{Result and Discussion}

\subsection{Number of Fertile Tillers per Plant}

The analysis of variance indicated that weeding frequency and variety significantly $(\mathrm{P}<0.05)$ interact on the number of productive tillers per plant (Table 1). GOBE variety with three times and two times weeding recorded the highest number of fertile tillers per plant. The lowest number of productive tillers was observed in weedy check of CROSS 41/98 and EH1493. The result of this study showed that the number of fertile tillers increased with the increase in weeding frequency. The higher fertile tiller per plant from increasing weeding frequency might be due to reduced intra plant competition. The lower number of tillers observed with CROSS 41/98 and EH1493 varieties along with weedy 
checks could be due to unavailability of more space for better light interception, and the reduction of nutrients and moisture availability as the result of weeds competition. Similarly, [9] reported that weeds are naturally strong competitor and compete with crops for space, nutrient, moisture, light and carbon dioxides that they could reduce yield and yield components of the crop.

Table 1. Interaction effect of weeding frequency and varieties on number of fertile tillers at Amuru district in 2016.

\begin{tabular}{|c|c|c|c|c|c|c|}
\hline \multirow{2}{*}{ Weeding frequency } & \multicolumn{6}{|c|}{ Varieties (V) } \\
\hline & HB-1307 & CROSS 41/98 & GOBE & EH1493 & Local & Mean \\
\hline Weedy check & $1.57^{\text {fehg }}$ & $0.47^{\mathrm{i}}$ & $1.23^{\text {ghfi }}$ & $0.47^{\mathrm{i}}$ & $1.03^{\text {ghi }}$ & 0.95 \\
\hline Once weeding & $1.61^{\text {ghefd }}$ & $1.4^{\text {ghfi }}$ & $2.0^{\text {gcefd }}$ & $0.9^{\text {hi }}$ & $1.5^{\text {ghef }}$ & 1.48 \\
\hline Twice Weeding & $2.43^{c e b d}$ & $2.83^{\mathrm{cb}}$ & $4.6^{\mathrm{a}}$ & $2.1^{\text {cefd }}$ & $2.0^{\text {gcefd }}$ & 2.39 \\
\hline Thrice Weeding & $2.63^{\mathrm{cb}}$ & $3.33^{\mathrm{b}}$ & $5.2^{\mathrm{a}}$ & $2.57^{\mathrm{cbd}}$ & $2.07^{\text {cefd }}$ & 3.16 \\
\hline Mean & 2.06 & 2.01 & 3.26 & 1.51 & 1.65 & \\
\hline \multicolumn{3}{|c|}{ LSD (0.05) Weeding frequency $\times$ Variety $=0.99$} & \multicolumn{4}{|c|}{$\mathrm{CV}(\%)=28.7$} \\
\hline
\end{tabular}

Means in columns and rows followed by the same letter are not significantly different at $1 \%$ or $5 \%$ probability levels.

\subsection{Plant Height}

Analysis of variance showed that the main effect weeding frequency and varieties had significant $(\mathrm{P}<0.01)$ influence on plant height (Table 2). Three times weeding produces significantly taller $(82.7 \mathrm{~cm})$ plants than plants in weedy check plots as well as one time and two times weeded plots. The mean plant height was increased by $12.7 \%$ for the plants in three times weeded compared to control. The decrease in height observed on crops with in weedy check could be attributed to high competition for sunlight as well as for space, moisture and nutrients. Similarly, El-Naim [10] reported that, increasing weeding frequency increased plant height, due to efficient weed control. Plants received sufficient nutrients, moisture and light grow taller and vigorous [11]. The main effect of varieties showed the presence of variation in plant height, and the tallest height were recorded on varieties CROSS $41 / 98(83.65 \mathrm{~cm})$ and HB-1307 $(83.52 \mathrm{~cm})$, while GOBE variety had the lowest $(63.3 \mathrm{~cm})$ plant height. However, there was no significant difference between EH1493 variety and Local cultivar in plant height which was moderate with mean of $79.09 \mathrm{~cm}$ and $80.5 \mathrm{~cm}$, respectively. This result agreed with [12] who reported that the presence of variation in plant height in different barley genotypes.

\section{Spike Length}

The length of spike plays a vital role in barley towards the kernel per spike and finally the yield. Analysis of variance indicated that frequency and varieties significantly $(\mathrm{P}<0.01)$ affect spike length, while no significant interaction between weeding frequency and variety (Table 2). Increased weeding frequency increased significantly spike length of barley. The longest spike length $(7.58 \mathrm{~cm})$ was recorded on three times weeded plots followed by two times weeded plots $(7.35 \mathrm{~cm})$, even though there was no significant difference between three times and two times weeding frequencies. The lowest spike length $(5.92 \mathrm{~cm})$ was recorded from weedy check. The reduction in spike length in weedy check could be attributed to high competition for growth resources. The result also demonstrated that the spike length was significantly $(\mathrm{P}<0.01)$ influenced by main effect of varieties. Local cultivar produced significantly longer $(8.25 \mathrm{~cm})$ spike length than other varieties. However; there was no significant difference between improved varieties. Khan reported that varieties have different genetic potential regarding the spike length [13].

Table 2. Interaction effect of weeding frequency and varieties on number of kernels per spike of Barley at Amuru in 2016.

\begin{tabular}{|c|c|c|}
\hline Treatment & Plant height (cm) & Spike length (cm) \\
\hline \multicolumn{3}{|l|}{ Weeding Frequency } \\
\hline Weedy check & $73.36^{d}$ & $5.92^{c}$ \\
\hline One time weeding & $76.83^{c}$ & $6.53^{b}$ \\
\hline Three times weeding & $82.7^{a}$ & $7.58^{a}$ \\
\hline LDS (0.05) & 2.15 & 0.35 \\
\hline \multicolumn{3}{|l|}{ Varieties } \\
\hline CROSS 41/98 & $83.65^{a}$ & $6.54^{b}$ \\
\hline GOBE & $63.3^{c}$ & $6.46^{b}$ \\
\hline EH1493 & $79.09^{b}$ & $6.66^{b}$ \\
\hline LOCAL & $80.51^{b}$ & $8.25^{a}$ \\
\hline $\operatorname{LSD}(0.05)$ & 2.4 & 0.39 \\
\hline $\mathrm{CV}(\%)$ & 3.73 & 7 \\
\hline
\end{tabular}

Means in columns and rows followed by the same letter are not significantly different at $1 \%$ or $5 \%$ probability levels. 


\subsection{Numbers of Kernels per Spike}

Number of kernels per spike was significantly $(\mathrm{P}<0.01)$ affected by the interaction of weeding frequency and varieties (Table 3). The highest number of kernels per spike was recorded with three times weeding with HB-1307, CROSS 41/98, and EH1493 varieties. The mean number of kernels per spike increased with increasing weeding frequency. This might be due to removal of weeds at early stages and the lateral removal of emerged weed community had contributed less completion with crop. This finding was agreed with [14] who report that the removal of weed from crop at earlier time could boost yield components and yield. Later weeding and hoeing after critical period of weed control would not enhance yield component and yield but create conducive environment for harvesting. However; the lowest number of kernels per spike was obtained with GOBE variety and Local cultivar with weedy check. This was due to the high infestation of weed which competed with the crop and thus results in agrees with the finding of [15] who report that number of kernels per spike was significantly reduced with the increase of weed infestation; and significantly increase with the weed free period. Moreover, in three times weeding treatment, kernels were health and completely filled, while kernels in weed cheek plots were shriveled and few in number. This was because of the effect of the competition for limited nutrients available, ultimately resulting in reduced kernel filling.

Table 3. Interaction effect of weeding frequency and varieties on number of kernels per spike of Barley at Amuru in 2016.

\begin{tabular}{|c|c|c|c|c|c|c|}
\hline Treatments & Varieties & & & & & \\
\hline Weeding Frequency & HB-1307 & CROSS 41/98 & GOBE & EH1493 & Local & Mean \\
\hline Weedy check & $37.05^{e}$ & $28.47^{d}$ & $18.1^{a}$ & $31.48^{d}$ & $18.81^{a}$ & 26.78 \\
\hline One time weeding & $38.24^{e}$ & $30.04^{d}$ & $19.05^{a b}$ & $37.57^{e}$ & $20.57^{a b c}$ & 29.09 \\
\hline Two times weeding & $46.43^{f g}$ & $44.19^{f}$ & $23.24^{b c}$ & $43.9^{f}$ & $20.95^{a b c}$ & 35.74 \\
\hline Three times weeding & $47.57^{f g}$ & $49.62^{g}$ & $23.62^{c}$ & $46^{f g}$ & $21.95^{a b c}$ & 37.75 \\
\hline Mean & 42.32 & 37.98 & 21.0 & 39.74 & 20.57 & \\
\hline \multicolumn{3}{|c|}{ LSD $(0.05)$ Weeding frequency $*$ Variety $=2.17$} & \multicolumn{4}{|c|}{$\mathrm{CV}(\%)=8.13$} \\
\hline
\end{tabular}

\subsection{Thousand Kernel Weight}

Thousand kernel weight was significantly $(\mathrm{P}<0.01)$ affected by main effects of weeding frequency and variety. However, their interaction effect was non-significant (Table 4). Thousand kernels weight significantly increased with increase in weeding frequency from zero (weedy check) to three times weeding. The higher thousand kernel weight $(46.26 \mathrm{~g})$ was recorded at a frequency of three times weeding and the lowest $(37.56 \mathrm{~g})$ was recorded from the control. The mean thousand kernel weight was increased by 3,16 and $23.2 \%$ due to one, two and three times weeding, respectively as compared to control. The highest thousand kernel weight which were recorded from three times weeding frequency might be due to absence of competition for resource with weed starting from crop emergence to harvest, since the plots were weed free. The lowest thousand kernel weight which was recorded from weed cheek was due to high infestation of weed population which had not disturbed till crop harvest. This finding was directly supported with the study of Neveed who report that weed are naturally strong competitor and compete with crop for space, nutrients, moisture, light, and carbon dioxide that they could reduce the weight of grain majorly $[16,9]$. Found that all yield components including thousand kernels weight are affected by weed management. Significant differences were observed between five barley genotypes in thousand kernel weight. The highest thousand kernel weights were obtained from HB-1307 (45g) and followed by CROSS 41/98 (42g), GOBE (42g) Local (41g) and EH1493 (38g) barley cultivars. Ge otypic variation played significant role in producing varied thousand kernel weights. Bedasa [17] obtain similar result on barley variety grown under irrigation.

Table 4. Main effect of varieties on yield and yield components of barley as influenced by weeding frequency at Amuru 2016.

\begin{tabular}{|c|c|c|c|}
\hline Treatment & TKW (g) & Grain yield $\left(\mathrm{Kg} \mathrm{ha}^{-1}\right)$ & Biological yield $\left(\mathrm{Kg} \mathrm{ha}^{-1}\right)$ \\
\hline \multicolumn{4}{|l|}{ Weeding Frequency } \\
\hline Weedy check & $37.56^{c}$ & $511.1^{d}$ & $1499.99^{b}$ \\
\hline One time weeding & $38.68^{c}$ & $644.44^{c}$ & $2055.55^{b}$ \\
\hline Three times weeding & $46.26^{a}$ & $1422.22^{a}$ & $3877.78^{a}$ \\
\hline $\operatorname{LDS}(0.05)$ & 1.48 & 172.2 & 754.54 \\
\hline \multicolumn{4}{|l|}{ Varieties } \\
\hline CROSS 41/98 & $42.45^{b}$ & $763.88^{b c}$ & $2138.89^{b}$ \\
\hline GOBE & $41.79^{b}$ & $958.33^{a b}$ & $2486.1^{b}$ \\
\hline EH1493 & $37.73^{c}$ & $541.55^{c}$ & $2430.6^{b}$ \\
\hline LOCAL & $40.97^{b}$ & $791.65^{b c}$ & $2386.9^{b}$ \\
\hline $\operatorname{LSD}(0.05)$ & 1.658 & 385.39 & 843.8 \\
\hline $\mathrm{CV}(\%)$ & 4.83 & 26.82 & 30.29 \\
\hline
\end{tabular}

Means in columns and rows followed by the same letter are not significantly different at $1 \%$ or $5 \%$ probability levels. 


\subsection{Grain Yield}

Weeding frequency and varieties significantly $(\mathrm{P}<0.01)$ affect grain yield of barley (Table 4), however, their interaction was not significant. The highest mean grain yield $\left(1422 \mathrm{~kg} \mathrm{~h}^{-1}\right)$ was obtained from three times weeded plots, while the lowest mean $\left(511 \mathrm{~kg} \mathrm{ha}^{-1}\right)$ was recorded from weedy check. Grain yield increases with increasing weeding frequency. The highest grain yield was obtained in three times weeded plots which were significantly higher than all the other treatments. The treatments having higher weed frequency in general resulted in higher grain yield.

This was supported by [18], who found similar results in wheat. Grain yield per hectare was found to be affected significantly $(\mathrm{P}<0.01)$ by barley varieties. Significantly higher grain yield $\left(1292 \mathrm{kgha}^{-1}\right)$ and $958 \mathrm{kgha}^{-1}$ were recorded for variety HB-1307 and GOBE while lower for CROSS 41/98 (764 kg ha-1), EH1493 (542 $\left.\mathrm{kgha}^{-1}\right)$ and the Local cultivar $\left(792 \mathrm{~kg} \mathrm{ha}^{-1}\right)$. This result agrees with the investigation of [19] who reported yielding variability of barley in Ethiopian barley genotypes.

\subsection{Biological Yield}

Main effect of weeding frequency and varieties significantly affect Biological yield of barley at $(\mathrm{P}<0.01)$ and $(\mathrm{P}<0.05)$, respectively (Table 4). Considerably higher $\left(3878 \mathrm{kgha}^{-1}\right)$ biological yield was obtained from three times weeded but didn't significantly differ from two times weeded $\left(3133 \mathrm{~kg} \mathrm{ha}^{-1}\right)$. The lowest $\left(1500 \mathrm{~kg} \mathrm{ha}^{-1}\right)$ biological yield was obtained from weedy check. These results indicated that weeding at different crop and weed stage had great influence on biological yield. $[20,15]$ reported that increased biological yield of the crop was highly governed by the length of weed free period. Similarly, reported that the removal of weeds from crop at earlier time could boost the yield components and yield. The lowest biological yield which was recorded from weedy check was due to competition between crops and weeds for light interception, available nutrients and moisture for both straw and grain accumulation. The result of the study also demonstrated that biological yield was influenced by main effect of varieties. Variety HB-1307 produced the largest (3514 $\left.\mathrm{kgha}^{-1}\right)$ biological yield, followed by Local $\left(2639 \mathrm{~kg} \mathrm{ha}^{-1}\right)$, GOBE $\left(2486 \mathrm{~kg} \mathrm{ha}^{-1}\right)$, and EH1493 (2431 $\left.\mathrm{kg} \mathrm{ha}^{-1}\right)$, while CROSS $41 / 98$ resulted in low biological yield $\left(1364 \mathrm{~kg} \mathrm{ha}^{-1}\right)$. The higher yielding varieties were found to have both greater biomasses. The result agrees with [21] who reported genotypes variability in biomass yield of barley.

\subsection{Harvest Index}

Analysis of variance indicated that the interaction effect of weeding frequency by variety significantly $(\mathrm{P}<0.01)$ influenced harvest index (Table 5). Highest harvest index obtained from three times weeding with GOBE variety (42.14\%), while the lowest $19.24 \%$ harvest index with two times weeding and variety EH1493. The variation in harvest index under different interactions was most probably due to variation in genotypes.

Table 5. Interaction effect of weeding frequency and Varieties on harvest index of barley at Amuru in 2016.

\begin{tabular}{lllllll}
\hline \multirow{2}{*}{ weeding frequency } & \multicolumn{2}{l}{ varieties } & & & \\
\cline { 2 - 7 } & hb-1307 & cross 41/98 & gobe & eh1493 & local & mean \\
\hline weedy check & $36.67^{\text {cdef }}$ & $27.67^{\text {fghi }}$ & $40.1^{a}$ & $29.63^{\text {efgh }}$ & $31^{\text {efgh }}$ & 33.02 \\
one time weeding & $37.51^{\text {bc }}$ & $35.35^{\text {cdefg }}$ & $36.77^{\text {bcd }}$ & $27.36^{\text {fghi }}$ & $24.26^{h i}$ & 32.25 \\
two times weeding & $34.62^{\text {cdefg }}$ & $37.01^{\text {bcd }}$ & $32.61^{\text {ffdgh }}$ & $19.24^{i}$ & $25.01^{\text {ghi }}$ & 29.04 \\
three times weeding & $39.35^{b}$ & $36.76^{\text {bcde }}$ & $42.14^{a}$ & $22.26^{i}$ & $38.98^{b c}$ & 36.04 \\
mean & 37.04 & 34.2 & 37.91 & 24.8 & 29.8 & \\
lsd $(0.05)$ weeding frequency $\times$ variety= & 3.52 & & cv (\%)=13.02 & & & \\
\hline
\end{tabular}

means in columns and rows followed by the same letter are not significantly different at $1 \%$ or $5 \%$ probability levels.

\section{Conclusion and Recommendation}

Based on the study, frequency of weeding and genotype of barley influence the productivity of barley in the study area. Three times weeding increased number of fertile tiller and kernels per spike, plant height, grain and biological yield, and harvest index of barley in the study area. Of the four varieties tested in the experiment, the higher biological and grain yields were obtained from HB-1307 barley. Nevertheless the overall yield of barley in the study area was found very low therefore, developing site specific varieties should be given due consideration. Moreover, determining the optimal time of sowing for the existing varieties is crucial due to erratic whether condition in the study area.

\section{References}

[1] Central Statistics Agency (CSA). 2015. Agricultural sample survey report on private peasant holdings, meher season 2014/20015 Volume I, Addis Ababa, Ethiopia.

[2] Bayeh Mulatu. \& Berhane Lakew. 2011. Barley research and development.

[3] Asnakew Woldeab, Tekalign Mamo, Mengesha Bekele and Tefera Ajema. 1991. Soil Fertility Management Studies on Wheat in Ethiopia. pp. 112-144. In: Hailu Gebre-Mariam, Tanner, D. G. and Mengistu Hulluka (Eds.). Wheat Research in Ethiopia: A Historical Perspective. IAR/CIMMYT, Addis Ababa. 
[4] Takele Negewo, Matias Mekuria \& Temam Hussien. 2006. Competition effects of major weed species at various densities on yield and yield components of barley (Hordeum vulgare L.), Journal of Ethiopia. 10: 53-59.

[5] Oromia Sustainable Land Management Program (OSLMP).2014. Amuru Woreda Multiyear Plan Document for Dero-Welage watershed Management, Oromia BoA assisted by GIZ-SLM.

[6] Fageria, N. K. 2009. The Use of Nutrients in Crop Plants $2^{\text {nd }}$ (Ed.) New York: CRC Press.

[7] SAS (Statistical Analysis System). 2003. SAS Version 9. 3. 2002-2003. SAS Institute.

[8] Gomez, K. A. and A. A. Gomez. 1984. Statistical procedures for agricultural research. ( $\left.2^{\text {nd }} E d.\right)$ A Wiley-International Publication John Wiley and Sons, Inc., New York.

[9] Naveed, M, Ahmad, R, Nadeem MA, Nadeem, SM, Shahzadand, K, and Anjum, MA. 2008. Effect of a new post emergence herbicide application in combination with urea on growth, yield and weeds control in maize (Zea mays L.). Journal of Agricultural Research, 46 (2): 31-47.

[10] El-Naim, A. M. Hagelsheep, M. E. Abdelmuhsin, A. E. Abdalla, 2010. Effect of Intra rowspacing on growth and yield of three cowpea (Vigna unguiculata L.) varieties under rain fed. Research Journal of Agriculture and Biological Sciences, 6 (5): 623629 .

[11] Kamel, M. S., M. S. Abdel-Raouf, E. A. Mahmoud and S. Amer, 1983. Response of two maize varieties to different plant densities in relation to weed control treatment. Journals of Agricultural Science, 19: 79-93.

[12] El-banna, M. N. M. A., EL Gawad Nassir, M. N. Mohammed and M. A. EL-Azeem Boseely 2011 Evaluation of 16 barley genotypes under calcareous soil conditions in Egypt. Journal of Agricultural Science. 3 (1): 105-121.

[13] Khan, M. A., J. Anwar, A. Sattar and M. A. Akhtar. 2001. Effect of seed rate on wheat yield under different sowing dates and row spacing J. Agric. Res. 39 (3-4): 223-229.
[14] Shrestha, A. Hanson, BD Fidel bus, M, W and Alcorta M. 2010. Growth, phenology, and intraspecific competition between glyphosate resistant and glyphosate susceptible horse weeds (Conyza canadensis) in the San Joaquin valley of California. Weed Science 58: 147-153.

[15] Zand, E. Baghestani, MA. Soufizadeh, S, Bagherani N and Deihimfard R. 2007. Weed control and wheat (Triticum aestivum L.) Yield under application of 2, 4-D plus carfentrazone ethyl and florasulam plus flumetsulam: Evaluation of the efficacy. Crop Protection, 26 (12): 1759.

[16] Ronis, A., Z. Dabkeviicus and Z. Liatukas, 2009. Influence of leaf diseases on grain yield and yield components in winter wheat. J. of Protection research. 49: 2: 152-157.

[17] Bedasa Mekonnon 2014. Selection of Barley Varieties for their Yield Potential at Low Rain Fall Area Based on both Quantitative and Qualitative Characters, Ethiopia. International Journal of Plant Breeding and Genetics, 8: 205-213.

[18] Haque, E., Kabir, G., Mondal, M. A. A. and Alam, A. M. S. 2003. Stability for yield components in wheat (Tritium aestivum L.). Bangladesh Journal of Plant Breeding Genetics. 16 (1): 39-44.

[19] Kemelew Muhe. and Alemayehu A., 2011. Diversity and agronomic potential of barley (Hordeum vulgare L.) in: variable production system, Ethiopia Journal of Agricultural Science Research. 1 (4): 148-154.

[20] Mizan A, Sharma J, Gebremedhin W. 2009. Estimation of critical period of weed crop competition and yield loss in Sesame (Sesamum indicum L.). Ethiopian Journal of Weed Management, 3 (1) 39-53.

[21] Yetsedaw Aynewa, Tadesse Dessalegn, and Wondimu Bayu. 2013. Participatory evaluation of malt barley (Hordeum vulgare L.) genotypes for yield and other agronomic traits at North-West Ethiopia. J. Agric Research, Vol. 2 (8), pp. 218222. 